\title{
Evaluation of systemic tissue involvement in mice following intraperitoneal inoculation of Toxoplasma gondii RH Ankara strain*
}

\author{
Toxoplasma gondii RH Ankara sușu ile intraperitoneal olarak enfekte \\ edilen farelerde sistemik doku tutulumunun değerlendirilmesi
}

Emine ŞAMDANCI-TÜRKMEN ${ }^{1}$, Ayşegül TAYLAN-ÖZKAN ${ }^{2-3}$, Cahit BABÜR ${ }^{3}$, Mesut MUNGAN ${ }^{3}$, Nasuhi Engin AYDIN $^{4}$

\section{ABSTRACT}

Objective: This study aimed to pathologically evaluate systemic tissue involvement in acute toxoplasmosis in mice inoculated with Toxoplasma gondii RH Ankara strain.

Method: Forty-two Mus musculus albino mice were divided into four groups with the control group receiving no inoculation, the group consisting of mice that were not sacrificed after intraperitoneal inoculation and the groups consisting of mice euthanasia were performed on day runner up or day fourth following intraperitoneal inoculation. A 48-50-hour intraperitoneal passage of $T$. gondii $\mathrm{RH}$ Ankara strain in mice was used for inoculation and each mouse received $5 \times 10^{4}$ tachyzoites. The mice sacrificed by euthanasia were macroscopically examined and then collected tissue samples fixed in $10 \%$ formalin. The preparations set by from the tissues blocked in paraffin were stained with hematoxylin-eosin and histopathological examination was performed.

Results: Necrosis in the serosa of the intestine and parenchyma of the liver, spleen, kidneys, pancreases and omentum and many free groups of tachyzoites were observed. Tachyzoites were identified in alveolar capillary lumens in the lungs. No pathological finding was observed in the cerebrum and cerebellum but few tachyzoites. It was observed that tissue necrosis and the density of Toxoplasma gondii tachyzoites were directly

\section{ÖZET}

Amaç: Bu çalıșmada, intraperitoneal yolla Toxoplasma gondii RH Ankara suşu inoküle edilen farelerde oluşan akut tokzoplazmozisde sistemik doku tutulumunun patolojik olarak değerlendirilmesi amaçlanmıștır.

Yöntem: Mus musculus varyete albino cinsi 42 adet fare, herhangi bir inokülasyonun yapılmadığı kontrol grubu, intraperitoneal inokülasyondan sonra sakrifiye edilmeyen ve intraperitoneal inokülasyondan ikinci gün ve dördüncü gün sakrifiye edilenler olmak üzere dört gruba ayrıımışıır. Farelerin intraperitoneal inokülasyonunda $T$. gondii RH Ankara sușunun farelerdeki 48-50 saatlik intraperitoneal pasajları kullanılmış ve her bir fareye $5 \times 10^{4}$ takizoit verilmiştir. Sakrifiye edilen hayvanlar makroskobik olarak incelendikten sonra alınan doku örnekleri \%10 formalinde tespit edilmiştir. Parafin bloklara alınan dokulardan hazırlanan preparatlar hematoksilen-eozin ile boyanarak histopatolojik olarak incelenmiștir.

Bulgular: Karaciğer, dalak, ince bağırsaklar, böbreklerin parankimi ve serozasında nekrozlar ve çok sayıda serbest takizoit grupları gözlenmiștir. Akciğerin alveolar kapiller lümenlerinde de takizoitler saptanmıştır. Beyin ve beyincikte ise herhangi anlamlı bir patolojik değișiklik izlenmemiștir. Dokulardaki nekroz ve Toxoplasma gondii takizoidlerinin yoğunluğunun, inokülasyon süresi ve temas yüzeyi ile doğru orantılı olduğu

* Presented at the $19^{\text {th }}$ National Pathology Congress at Girne, Cyprus, October 07-11, 2009.

${ }^{\prime}$ Inönü University, Faculty of Medicine, Department of Medical Pathology, MALATYA, TURKEY

${ }^{2}$ Hitit University, Faculty of Medicine, Department of Medical Microbiology, CORUM, TURKEY

${ }^{3}$ Public Health Institution of Turkey, National Parasitology Reference Laboratory, ANKARA, TURKEY

${ }^{4}$ Izmir Katip Celebi University, Department of Medical Pathology, IZMIR, TURKEY

İletişim/Corresponding Author: Ayşegül TAYLAN-ÖZKAN

Hitit University, Faculty of Medicine, Department of Medical Microbiology, CORUM, TURKEY Gelis Tarihi / Received : 16.07.2014

Tel : +093124582474

E-posta/E-mail : aysegultaylanozkan@yahoo.com

Kabul Tarihi / Accepted : 07.11.2014

DOI ID : 10.5505/TurkHijyen. 2015.32448

Samdancı-Türkmen E, Taylan-Özkan A, Babür C, Mungan M, Aydın N.E. Evaluation of systemic tissue involvement in mice following intraperitoneal inoculation of Toxoplasma gondii RH Ankara strain. Turk Hij Den Biyol Derg, 2015; 72(1): 27-36. 
proportional to the duration of post inoculation. All infected mice that received no intervention died on day sixth. In this study in mice, it was found that $T$. gondii $\mathrm{RH}$ Ankara strain induced the same pathological findings as the RH strain belonging to the virulent Type I group.

Conclusion: Mice inoculation can be used for diagnosis and this model may also be used in studies investigating vaccination, drugs and pathogenesis.

Key Words: Toxoplasma gondii, pathogenesis, mice gözlenmiștir. Herhangi bir müdahalede bulunulmayan enfekte farelerin tamamı altıncı günün sonunda ölmüștür. Bu çalıșmada $T$. gondii RH Ankara suşunun farelerde virulan Tip I gruba bağlı RH suşlarındakine benzer patolojik bulgular olușturduğu belirlenmiștir.

Sonuç: Fare inokülasyonu tanı amacıyla kullanılabileceği gibi aşı, ilaç ve patogeneze yönelik çalıșmalarda da bu modelden yararlanılabilir.

Anahtar Kelimeler: Toxoplasma gondii, patogenez, fare

\section{INTRODUCTION}

Toxoplasma gondii is an obligate intracellular parasite which is common worldwide and has a high prevalence in the communities. The definitive host of $T$. gondii is the cat and the intermediate hosts are vertebrates such as human beings, birds, cattle, sheep and goats. The parasite has three infective stages: trophozoites (tachyzoites), bradyzoites, and oocysts. Tachyzoites are the form of the parasites that rapidly multiplies in nucleated cells of the host by endodiogeny and can be produced in experimental animals and tissue cultures. Bradyzoites are the stage of the parasite that slowly multiplies in tissue cysts. Oocysts are the final product of the sexual stage in the intestinal epithelium of felines and are excreted in feces. Although the main mode of transmission in humans is the oral intake of oocysts, the disease may also be transmitted via products such as raw meat and milk that have the tissue cysts of the disease. Furthermore, toxoplasmosis is also acquired from other humans via maternofetal transmission or by organ transplantation and blood transfusion. After the acquisition of the parasites by any route, they enter macrophages and start to divide and hide from the humoral and cellular immune system during this period. T. gondii within the macrophages disseminate to all organs via the lymphatic system and blood (1-3).

Toxoplasmosis is prevalent in warm and humid climates and generally asymptomatic in individuals with a healthy immune system. However, immunocompromised patients as well as pregnant women and their fetuses are at risk. It was reported that the pathology in the host tissue induced by $T$. gondii infection has an important role in latent infection and reactivation processes, but the pathological features in humans induced by acute toxoplasmosis could be documented only in a few reports (1).

The diagnosis of toxoplasmosis is made by direct and indirect methods. Direct diagnosis is based on the demonstration of the causative agent in biopsy or autopsy/necropsy. The histopathological causative agent itself may be identified, while inoculation into cell culture or experimental animals may also be performed. This method is particularly useful in immunosuppressive patients or in cases such as AIDS where antibody production is low or late. Identification of the typically crescent-shaped $T$. gondii organisms by using various staining methods is a definitive diagnostic finding, but differentiation requires experience. For indirect diagnosis, immunological methods such as ELISA (Enzyme-Linked Immuno Sorbent Assay), IFAT (Indirect Fluorescent Antibody Test), and SFDT (Sabin Feldman Dye Test) are used. However, the decision regarding diagnosis of acute toxoplasmosis using indirect methods is quite difficult (3-6). Haholu et al. (5), suspected this infection in a patient based on the presence of many histiocytes in the lymphatic tissue samples obtained by fineneedle aspiration and the presence of particles in the cytoplasms of these histiocytes and made the definitive diagnosis by PCR. Although molecular 
methods have come to foreground particularly in congenital toxoplasmosis, immunosupressive patients or toxoplasmic encephalitis during the recent years, the combined use of the methods increases the possibility of success. PCR with amniotic fluid, fetal blood and peripheral maternal blood, inoculation into mouse peritoneum and culture were reported to be the most valid methods for the diagnosis of congenital toxoplasmosis in pregnancy (3-6).

Investigation of the physiopathology of toxoplasmosis is very important for the development of diagnosis, treatment and vaccination or other protective measures. These types of studies are performed in vivo and/or in vitro using strains with various levels of virulence and different animal models. It is noted that animal models would be useful in experimental modeling of chronic toxoplasmosis as well as disseminated toxoplasmosis seen in AIDS patients $(1,6-12)$.

This study aimed to pathologically evaluate the systemic tissue involvement in acute toxoplasmosis in mice induced by the intraperitoneal inoculation of $\mathrm{RH}$ Ankara strain.

\section{MATERIALS AND METHODS}

3-6-week-old healthy white male Swiss-Albino mice weighing approximately $20 \mathrm{~g}$ (Mus musculus albino) were provided from the Experimental Animal Production Laboratory of Refik Saydam Hygiene Center (RSHC). Care of mice and antigen production was provided by staff with Certificate of Experimental Animal use and performed under the approval of the Experimental Animals Local Ethics Committee of RSHC. Calf fattening meal and sterile water were used for feeding the animals throughout the study. Temperature, light and humidity were continuously controlled.

Although the mice used in the study are produced as "specifically pathogen-free (SPF)", they were examined for $T$. gondii antibodies using Sabin Feldman Dye Test (SFDT) by taking blood samples (2). Forty-two male Mus musculus albino mice, determined to be seronegative for $T$. gondii infection were included in the study. The animals were divided into the following groups: I) control group - intact animals (6 mice); II) control group - infected animals (6 mice); III) the animals sacrificed on day two following intraperitoneal inoculation (15 mice); and IV) the animals sacrificed on day four following intraperitoneal inoculation (15 mice).

48-50-hour passages of $T$. gondii RH Ankara strain in mice currently used as antigen in SFDT and IFAT in RSHC were used to established toxoplasmosis infection. Peritoneal exudates obtained from mice were adjusted so as to provide a tachyzoite count of $2.5 \times 10^{5} / \mathrm{mL}$ on Thoma slide by dilution with sterile normal saline and this prepared inoculum was administered to the mice in Group II, III and IV at a dose of $200 \mu \mathrm{L}\left(5 \times 10^{4}\right)$ by intraperitoneal injection $(2,13)$.

On day two and four following injection, necropsies were performed and tissue samples were taken from all organs systemically and the samples were fixed in $10 \%$ formalin after the mice were administered carbon dioxide. Following routine tissue examination, the samples were embedded in paraffin, cut into $5-\mu$ sections and stained with hematoxylin-eosin $(\mathrm{H}-\mathrm{E})$. The lesions induced by Toxoplasma that were found in the sections examined using light microscopy were evaluated for expansion and severity of involvement (14).

Control groups also sacrificed and histopathologically investigated at the end of the experiment.

\section{RESULTS}

Acute toxoplasmosis was detected in all intraperitoneally inoculated mice. No signs were found in the uninfected mice in Group I. Of the mice in Group II which were infected but did not undergo necropsy, four died on day five and two died on day 6 . It was observed that the mice infected with toxoplasmosis had hair erection and their mobility and feeding/drinking activities were decreased (Table 1). 


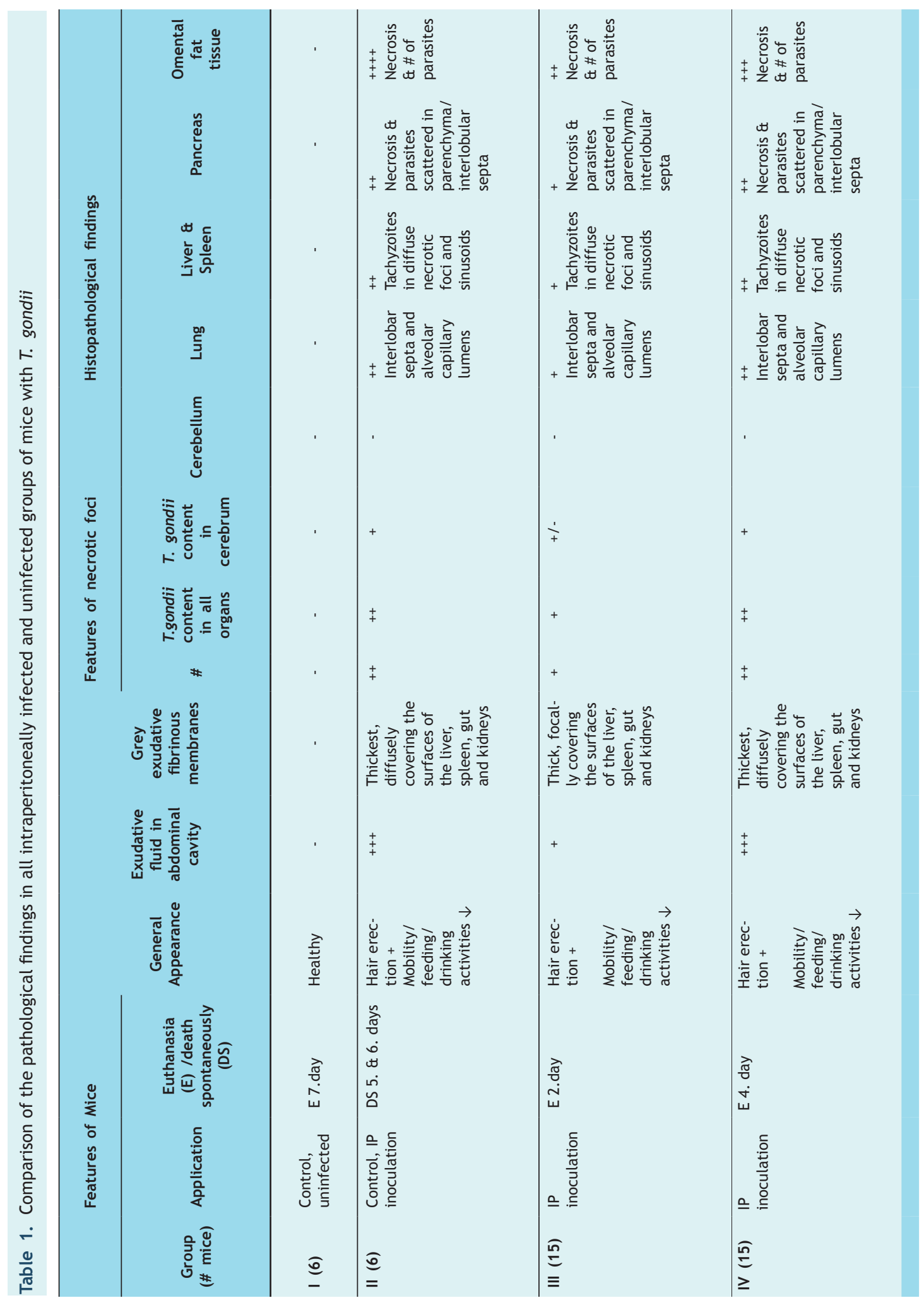


All mice which were given the causative agent intraperitoneally and euthanasia performed (Group III and IV) had 0.5-1 mL of exudative fluid in their abdominal cavity, a finding which was more pronounced on day four. Grey exudative fibrinous membranes focally or diffusely covering the surfaces of the liver, spleen, gut and kidneys were observed (Figure 1, 2 a, 2 b). Similar findings were seen Group II, too.

Microscopic examination revealed that the number of the necrotic foci and the microorganism content in these foci were higher in mice where euthanasia was performed on day 4 . In both groups, an appearance consistent with the parasite was very rare in the cerebrum of the mice and no significant pathological finding was observed in the cerebellums of the mice.

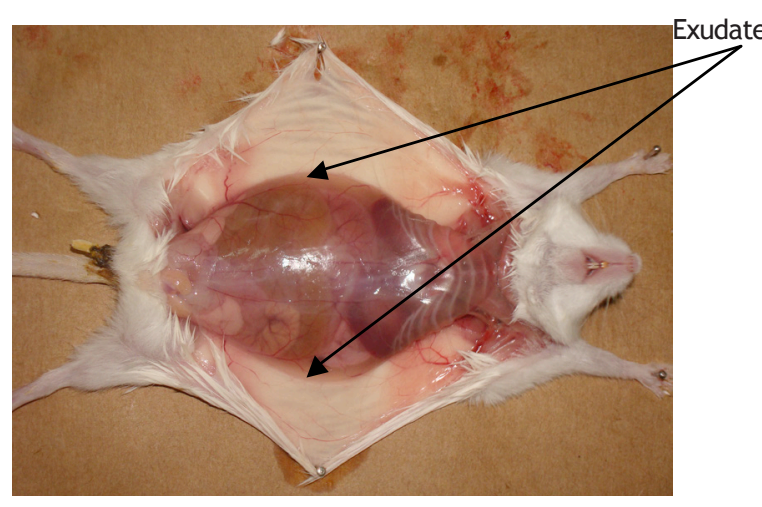

Figure 1. Appearance of the internal organs and formed exudate in a mouse euthanasia were performed 2 days after intraperitoneal inoculation of $T$. gondii RH Ankara strain.
Parasites were found in interlobar septa and alveolar capillary lumens in the lungs (Figure 3, 4). Tachyzoite forms were observed in diffuse necrotic foci and sinusoids in the liver and spleen (Figure 5). The presence of necrosis together with the parasite was found scattered in the parenchyma and interlobular septa in the pancreas. The density of both necrosis and parasites were determined to be higher in omental fat tissue compared to other tissues (Figure 6). The thickness of the fibrous exudative membrane covering the surface of the organs, the presence of necrotic foci and the density of parasites were higher in the group that was sacrificed on day four, directly proportional to the duration of infection.

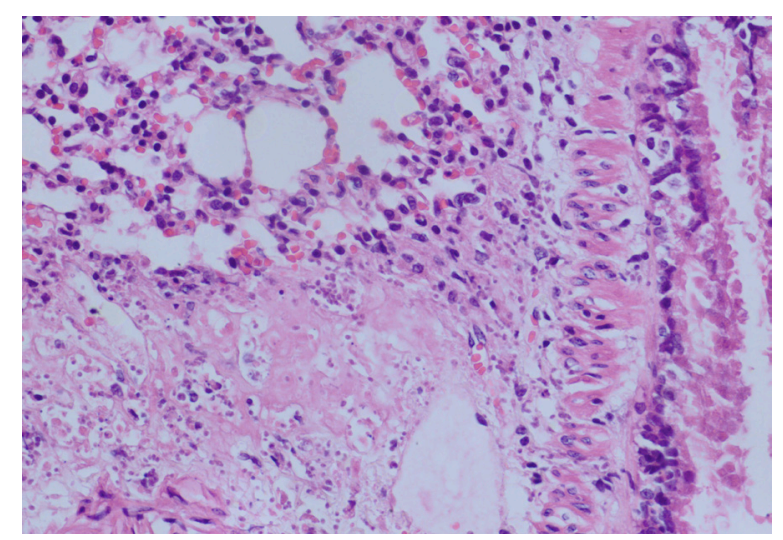

Figure 3. Trophozoites localized peribronchiolar (H-E X400)

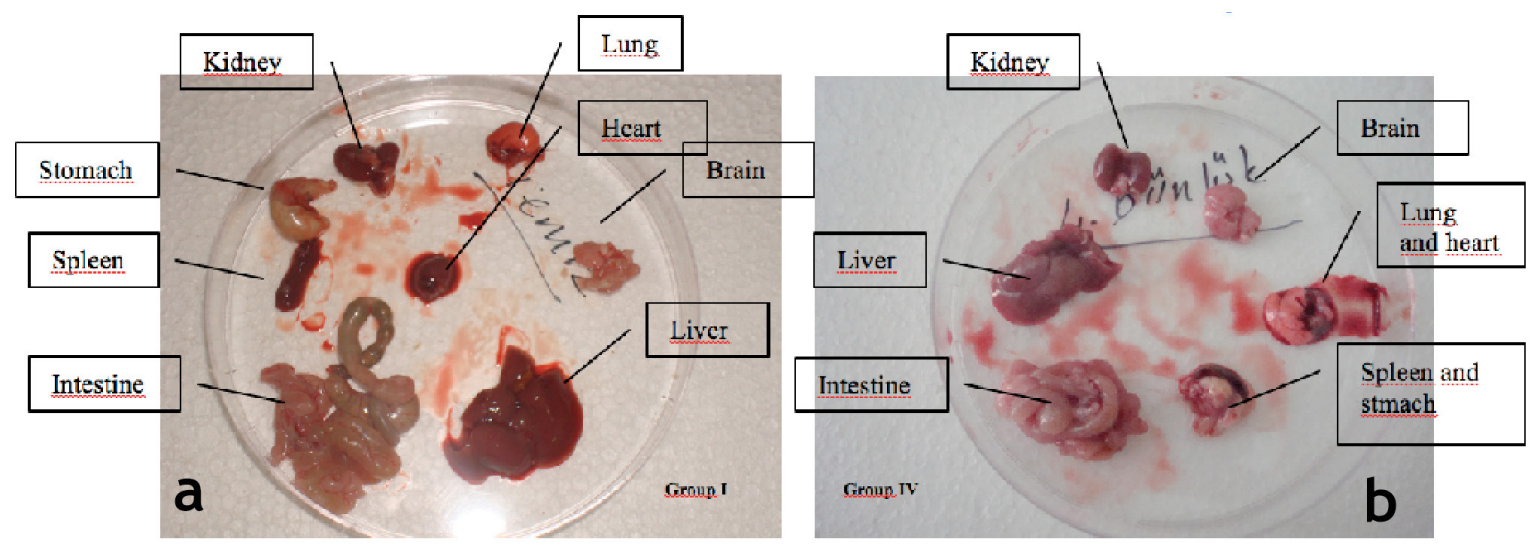

Figure 2. a) Appearance of the internal organs of the mice in Group I (Control group - intact mice) and

b) Group IV (euthanasia were performed 4 days after intraperitoneal inoculation of $T$. gondii RH Ankara strain). 


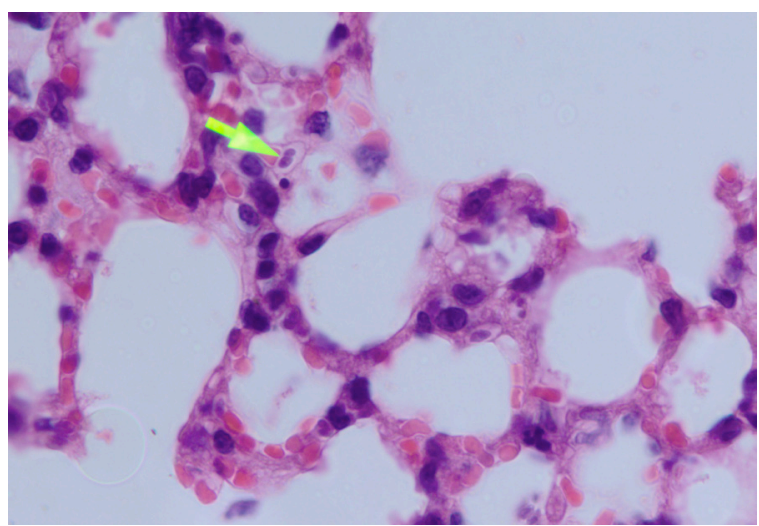

Figure 4. Toxoplasma parasite in alveolar capillaries (H-E X1000)

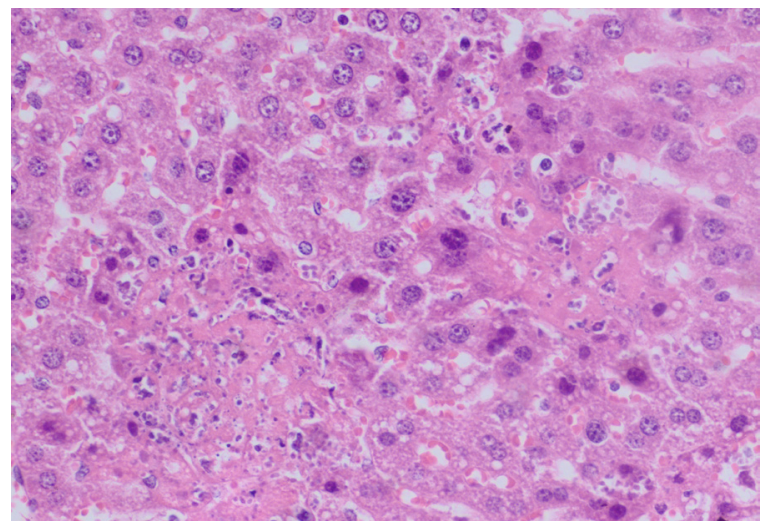

Figure 5. Necrotic foci and Toxoplasma parasites in the liver $(\mathrm{H}-\mathrm{E}$ X400)

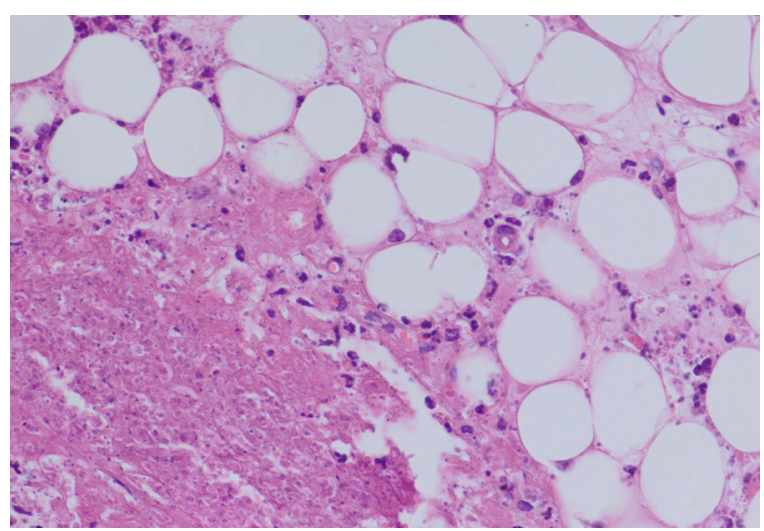

Figure 6. A necrotic area and dense Toxoplasma tachyzoites in the omentum (H-E X400)

\section{DISCUSSION}

Toxoplasma gondii can spread to the most distant organs by the lymphatic system and/or blood. In general, the first finding is necrosis in the intestinal and mesenteric lymph nodes in case of oral transmission of oocysts. Subsequently, focal necrosis areas may develop in many other organs. Toxoplasma produces no toxins and necrosis is caused by intracellular proliferation of tachyzoites. The clinical picture is determined by the damage in vital and sensitive organs such as eyes, adrenal glands, and heart and the immune system of the host. In humans, the symptoms of the infection are seen at a rate of $10 \%(3)$.

T. gondii has three main genotypes namely Type I, Type II and Type III. Type II strain is responsible for most of the toxoplasmosis cases affecting humans. The speed of infection of the host cell depends on the virulence of the Toxoplasma strain and this difference affects host and tissue selection of the parasite. In in vitro and in vivo studies, Type I strains were demonstrated to spread more rapidly and infect more cells compared to Type II and Type III. The lifecycles of virulent and avirulent strains of $T$. gondii in nature are also different and virulent strains more rarely form oocysts or tissue cysts $(8,15-20)$.

In studies using cell cultures, it was reported that $40 \%$ of cells were caught by the causative agent at 20 minutes of the infection with the $\mathrm{RH}$ strain. Furthermore, cells are destroyed within 24-48 hours of infection, while this period varies depending on the cell type (16). In studies conducted in our country, it was reported that the Ankara strain has the same structure as the RH strain, does not show a different performance than the RH strain in tests like ELISA and IFAT although Western blot analysis reveals some different protein bands and kills mice that are intraperitoneally infected within 4-6 days $(7,10,15$, 16, 21).

In mice in which acute toxoplasmosis was established by intraperitoneal inoculation, it was found that the activities of the animals were decreased, all hairs were erected, the water and food intake was 
rare, the animals lost weight and died in seven days (22). In a study investigating four different strains in mice and hamsters, it was reported that $\mathrm{RH}, \mathrm{T}-1$, and T-45 strains were always fatal in mice, while in hamsters RH strain caused the same outcome and Ts-4 caused milder infections in both species (17). It was noted that rats are more resistant to toxoplasmosis compared to mice and although it is believed that this resistance increases with age, the main effect depends on the strain and the administered dose (23).

The RH Ankara strain that we used in our study markedly showed the virulence features of Type I genotype and caused the death of all mice that were infected and received no intervention within six days as in the studies of Waree et al. (22) and Elwell and Frenkel (17).

In rats in which acute toxoplasmosis was established by intraperitoneal administration of $T$. gondii $\mathrm{RH}$ strain, the surface of the intraabdominal organs were covered by a white fibrinous exudate which was more intense on the liver, spleen and stomach, accompanied by thickening and adhesions in the omentum, pale spots in the liver sections and enlargement of the pelvic organs. In mice, it was noted that parasitic invasion was more intense in the liver and intracellular forms were present both in Kupffer cells and in the liver cells themselves and moreover, although necrosis were found in the surface of spleen, pancreas, stomach and kidneys, no abnormalities were observed in the cerebrum, spinal cord and meninges (24). In a similar study, it was reported that characteristic signs developed in the lymphoid system of mice and a marked enlargement of spleen and a decrease in lymphocyte count were observed and, moreover, the hypertrophy in the spleen started at the 6th hour and the enlargement lasted until death $(18,25)$.

In our study we also observed similar macroscopic appearances and presence of tachyzoites with an intensity that increased in direct proportion with the duration of infection in the spleens of all groups of mice that were sacrificed after $T$. gondii inoculation.
In a study in mice, T. gondii RH strain caused a more serious disease presentation compared to the avirulent Beverly strain and diffuse consolidation and severe congestion in the lungs, hyaline degeneration in cardiac muscle, focal necrotic areas in the liver, spleen and kidneys as well as thickening in the meninges were found (20). Intraperitoneal inoculation of Prugniaud strain resulted in dissemination to the brain in mice and rats among other organs $(11,26)$. In two separate studies in mice using intraperitoneal inoculation, significant congestion and necrosis in the liver, spleen and pancreas and mild to moderate congestion in the cerebral parenchyma were detected, while no or very few $T$. gondii tachyzoites were observed and no pseudocysts could be found in the brain $(1,22)$.

In our study, our findings were similar to the findings of other investigators $(1,20,22,26)$ with the exception of low number of tachyzoites in the brain and congestion in the heart.

Hazıroğlu et al. (14), reported that in rabbits they infected by intraperitoneal inoculation, necrotic lesions started from the serosal surfaces of the abdominal organs and their expansion and depth depended on the time elapsed since the inoculation in the group with both intravenous and intraperitoneal lesions. Macroscopically a yellowish fibrinous exudate covered all abdominal organs and serous surfaces and there were petechial hemorrhages in addition to the subcapsular necrotic foci in organs and focal pneumatic areas in the lungs. Microscopically, the necrotic areas starting from the serosal surfaces of the internal organs in the abdominal cavity increased in depth in the following days. It was found that inflammatory cells transformed into mononuclear cells and while the lesions were particularly localized in the liver, spleen and serosal surfaces in abdominal cavity (intestine, stomach, pancreas, urogenital system) they were relatively rare in the pancreatic interstitial tissue. Although lung lesions were found in a small number of rabbits, the lesions were reported to be mild in the brain and kidneys (14). 
In our study, the tachyzoite forms of RH Ankara strain that has similar characteristics with Type I genotype RH strain (the most virulent strain) were given intraperitoneally and in mice that euthanasia were performed on day two and four, intense necrotic areas were detected in the liver, spleen and pancreas, while a small number of no tachyzoites or pseudocysts were found in the cerebrum and no tachyzoites or pseudocysts were observed in the cerebellum. These findings are similar to the findings of Sukthana et al. (1), Waree et al., Armstrong and Fulton and Hazıroğlu et al., while they are different from the findings of Eissa et al. and Zenner et al. (14, 20, 22, 24, 26).

The susceptibility of the host, the stage of the parasite and the route of administration of the antigen affect the virulence of $T$. gondii. Different strains may cause different clinical presentations; some of these may be virulent and fatal, while others may result in cystic forms in the brain and muscles by causing chronic infection. It was reported that, in rats, the chronology of the infected organs changed depending on the route of administration of RH tachyzoites; with intraperitoneal inoculation, the organs in the peritoneal cavity were initially infected and subsequently all organs were infected via the bloodstream, while with oral route, initially mesenteric lymph nodes and then the spleen were infected, followed by dissemination to all organs via the bloodstream (26). Hence, in the study of Eissa et al. (20), the cysts in the brain occurred following chronic infection established by using a different strain. The studies of Zenner et al. $(11,26)$, also suggest that different routes of administration and different animal models as well as use of strains that cause chronic infection cause the differences in the results. Knowing the route of dissemination would be useful in predicting the path that the parasite will follow according to the mode of infection with T. gondii.

In conclusion, it was found that the morphological changes induced by the most virulent genotype of RH Ankara T. gondii strain following its intraperitoneal inoculation increased in direct proportion to the duration of direct contact and exposure to the causative agent. As determined in previous studies, RH Ankara strain is a virulent strain and caused pathological signs in organs similar to $\mathrm{RH}$ strain. We think that this study will be useful in understanding the pathogenesis of $T$. gondii tachyzoites in systemic organs and in establishing an experimental model for use in further diagnosis, treatment and vaccination studies. Moreover, this study aimed to demonstrate that animal inoculation could be used in the diagnosis of congenital infection in pregnancy or in people with impaired antibody production, including patients with AIDS or malignancy, and to attract the attention of our colleagues to the importance of cytopathology in the etiology of lymphadenopathy and hepatosplenomegaly.

\section{REFERENCES}

1. Sukthana $Y$, Waree P, Pongponratn E, Chaisri U, Riganti M. Pathologic study of acute toxoplasmosis in experimental animals. Southeast Asian J Trop Med Public Health, 2003; 34(1): 16-21.

2. Ozkan AT, Celebi B, Babür C, Lucio-Forster A, Bowman DD, Lindsay DS. Investigation of antiToxoplasma gondii antibodies in cats of the Ankara region of Turkey using the Sabin-Feldman dye test and an indirect fluorescent antibody test. J Parasitol, 2008; 94(4): 817-20.
3. Dubey JP. Toxoplasma gondii in medical microbiology Baron S, ed. 4th edition. Galveston (TX): University of Texas Medical Branch at Galveston, 1996.

4. Buffalano W, Beghetto E, Del Pezzo M, Spadoni A, Cristina $M$, Petersen $E$, et al. Use of recombinant antigens for early postnatal diagnosis of congenital toxoplasmosis. J Clin Microbiol, 2005; 43: 5916-24. 
5. Haholu A, Yıldırım S, Koru O, Ardıç N, Baloglu H. Toksoplazma gondii lenfadenitinin sitolojik tanısı: Olgu sunumu. Türk Patoloji Dergisi, 2006; 22(1): 57-60.

6. Piergili Fioretti D. Problems and limitations of conventional and innovative methods for the diagnosis of toxoplasmosis in humans and animals. Parasitologia, 2004; 46(1-2): 177-81.

7. Döskaya M, Degirmenci A, Ciçek C, Ak M, Korkmaz M, Gürüz Y, et al. Behaviour of Toxoplasma gondii RH Ankara strain tachyzoites during continuous production in various cell lines. Parasitology, 2006; 132(Pt 3): 315-9.

8. Djurković-Djaković O, Nikolić A, Bobić B, Klun I, Aleksić A. Stage conversion of Toxoplasma gondii $\mathrm{RH}$ parasites in mice by treatment with atovaquone and pyrolidine dithiocarbamate. Microbes Infect, 2005; 7(1): 49-54.

9. Araujo FG, Remington JS. Effect of clindamycin on acute and chronic toxoplasmosis in mice. Antimicrob Agents Chemother, 1974; 5(6): 647-51.

10. Delibas SB, Ertabaklar H, Ertug S. Evaluation of antigenic variations between two virulent Toxoplasma strains. J Medical Microbiol, 2006; 55: 1333-5.

11. Zenner L, Foulet A, Caudrelier Y, Darcy F, Gosselin B, Capron A, et al. Infection with Toxoplasma gondii $\mathrm{RH}$ and prugniaud strains in mice, rats and nude rats: kinetics of infection in blood and tissues related to pathology in acute and chronic infection. Pathol Res Pract, 1999; 195(7): 475-85.

12. Sibley LD, Mordue D, Howe DK. Experimental approaches to understanding virulence in toxoplasmosis. Immunobiology, 1999; 201(2): 210-24.

13. Ekmen H, Altıntaş K. Bir köpekten Toxoplasma izolmanı. Turk Hij Tec Biol Derg, 1973; 33: 17-20.

14. Hazıroglu R, Altıntas K, Atasever A, Gulbahar MY, Kul $O$, Tunca R. Pathological and immunohistochemical studies in rabbits experimentally infected with Toxoplasma gondii. Turk J Vet Anim Sci, 2003; 27:285-93.
15. Yaman K, Aral Akarsu G, Güngör C, Ataoğlu H. Toxoplasma gondii'nin çeșitli sușlarının proteinlerinin karakterizasyonu. Turk Parazitol Derg, 2011; 35: 133-6.

16. Yaman K. Toxoplasma gondii antijenlerinin karakterizasyonu. Yüksek Lisans Tezi, Ankara Üniversitesi Sağlık Bilimleri Enstitüsü, 2007.

17. Elwell MR, Frenkel JK. Acute toxoplasmosis in hamsters and mice: measurement of pathogenicity by fever and weight loss. Am J Vet Res, 1984; 45(12): 2663-7.

18. Csóka R, Császár S. The lymphoid system of Toxoplasma infected mice. Acta Microbiol Hung, 1983; 30(1): 43-6.

19. Djurković-Djaković O, Klun I, Khan A, Nikolić A, Knezević-Usaj S, Bobić B, et al. A human origin type II strain of Toxoplasma gondii causing severe encephalitis in mice. Microbes Infect, 2006; 8(8): 2206-12.

20. Eissa MH, Antonious SN, Salama MM, Fikry AA, Morsy TA. Histopathological studies of acute, chronic and congenital infections of toxoplasmosis in mice. J Egypt Soc Parasitol, 1990; 20(2): 805-16.

21. Degerli K, Kilimcioglu AA, Kurt O, Tamay AT, Ozbilgin A. Efficacy of azithromycin in a murine toxoplasmosis model, employing a Toxoplasma gondii strain from Turkey. Acta Trop, 2003; 88: 45-50.

22. Waree P, Ferguson DJ, Pongponratn E, Chaisri U, Sukthana Y. Immunohistochemical study of acute and chronic toxoplasmosis in experimentally infected mice. Southeast Asian J Trop Med Public Health, 2007; 38(2): 223-31.

23. De Champs C, Pelloux H, Dechelotte P, Giraud JC, Bally N, Ambroise-Thomas P. Toxoplasma gondii infection in rats by the $\mathrm{RH}$ strain: inoculum and age effects. Parasite, 1998; 5(3): 215-8.

24. Armstrong JA, Fulton JD. Observations on the pathology of toxoplasmosis in the cotton rat. $\mathrm{Br} \mathrm{J}$ Exp Pathol, 1959; 40(3): 225-31. 
25. Szeri I, Csóka R. Studies on the lymphoid system of mice with lethal acute toxoplasmosis. Acta Microbiol Acad Sci Hung, 1976; 23(3): 235-7.
26. Zenner L, Darcy F, Capron A, Cesbron-Delauw MF. Toxoplasma gondii: kinetics of the dissemination in the host tissues during the acute phase of infection of mice and rats. Exp Parasitol, 1998; 90(1): 86-94. 